\title{
Unresolved Injustice: An Examination of Indigenous Legal Issues in Australia
}

\author{
Rachael Asher* \\ Asia Pacific College of Business and Law, Charles Darwin University-Australia
}

Article Received: 26 ${ }^{\text {th }}$ June 2020; Accepted: $21^{\text {st }}$ July 2020; Published: $30^{\text {th }}$ July 2020

\begin{abstract}
Indigenous legal issues are to some extent a neglected and misunderstood subject in the Australian political and legal sphere. Where there is unresolved injustice, there is suffering. Similarly, where there is misunderstanding, there is ignorance. Therefore, the purpose of this paper is to explore Indigenous legal issues and potential solutions through an examination and analysis of relevant sources. The subjects of discussion in this paper include the limited extent that Aboriginal customary law is recognised under Commonwealth law; the impact of Australian law on Indigenous people; the over-representation of Indigenous people in the criminal justice system; the inadequate state of Indigenous property rights; and comparative law methodology.
\end{abstract}

Keywords: Aboriginal customary law; Indigenous legal systems; Indigenous crime; Indigenous property rights; comparative law.

How to cite: Asher, Rachael. "Unresolved Injustice: An Examination of Indigenous Legal Issues in Australia". Udayana Journal of Law and Culture 4, no. 2 (2020): 146-170. https://doi.org/10.24843/UJLC.2020.v04.i02.p02

doi: https://doi.org/10.24843/UJLC.2020.v04.i02.p02

\section{Introduction}

Australian governments need to make further amends for the suffering that is experienced by Indigenous Australians flowing from the unresolved injustices of the past and present. These injustices include the acquisition of this continent by the British Crown without consent; the many harms perpetrated against Indigenous Australians by government authorities thereafter; and the many harms perpetrated by private actors and tolerated by government authorities. The making of amends is a continuing moral obligation that will not be discharged until the suffering of Indigenous people is legally resolved to the fullest extent possible.

* Email/Corresponding Author: Email: rachaelasher@outlook.com.au 
Thus, Indigenous legal issues should be at the forefront of the political agenda at national, state, and territory levels in order to fulfil this duty. Accordingly, this paper aims to illuminate some of the principal Indigenous legal issues that remain to be resolved, and potential solutions, in order to encourage law reform. Furthermore, this paper aims to increase understanding about Indigenous legal issues by examining research methods that can break through Indigenous conceptual cultural barriers.

The findings are gathered by reference to relevant sources including legislation, case law, reports, and journal articles. The main topics of discussion in this paper include the limited extent that Aboriginal customary law ('ACL') is recognised in the Commonwealth jurisdiction; how Australian law impacts the life of Indigenous people; the over-representation of Indigenous people in the criminal justice system; the inadequate state of Indigenous property rights; and the challenges associated with understanding Indigenous legal issues that are surrounded by conceptual cultural barriers.

\section{Result and Analysis \\ 2.1. Recognition of Aboriginal Customary Law}

ACL is recognised to a limited extent in the Commonwealth jurisdiction. ${ }^{1}$ The term 'recognise' is understood herein as meaning 'to acknowledge formally as existing ...' unless otherwise stated. ${ }^{2}$ Research suggests that in Aboriginal tradition the term 'law' can be construed as encompassing features that do not fall within a commonly understood definition of law. ${ }^{3}$ For this reason, law is conceived of broadly in this paper in order to incorporate the Aboriginal conception of law that may, from a non-Aboriginal perspective, have similarities with 'shared norms', 'rules' and 'values'. ${ }^{4}$

1 Heather McRae et al. Indigenous Legal Issues: Commentary and Materials (Sydney: Thomson Reuters, 2009), 111-112 para 2.470, 114 para 2.520.

${ }^{2}$ Australian Law Reform Commission (i), "Recognition of Aboriginal Customary Laws content/uploads/2019/08/ALRC31.pdf [98]. 1986," https://www.alrc.gov.au/wphttps://www.macquariedictionary.com.au/features/word/search/?search_word_type=Dictiona ry\&word=recognise, para 4.

${ }^{3}$ McRae, op.cit., 69 para 2.50, quoting Law Reform Commission of Western Australia (K Trees), "Contemporary Issues Facing Customary Law and the General Legal System: Roebourne - A Case Study (Background Paper No 6, 2004)," https://researchrepository.murdoch.edu.au/id/eprint/11948/1/contemporary_issues_facing.. ..pdf, 218-219.

${ }^{4}$ Australian Law Reform Commission (i), op.cit., paras 99-100. 


\subsubsection{A Description of Aboriginal Customary Law}

ACL is composed of traditional rules that have been observed by Aboriginal Australians for several millennia. 5 Some of the categories of Aboriginal law include marriage, kinship systems, crime, land, and dispute resolution, and the content of the law differs between groups. ${ }^{6}$ Violations of the law can attract various penalties depending on the specific Aboriginal group and the offence. ${ }^{7}$ For example, spearing off the body and punishment by way of sorcery. ${ }^{8}$ ACL is a form of religious law and it is transmitted via unwritten modes such as oral communication and art. 9

\subsubsection{The Extent that Aboriginal Customary Law is Recognised 2.1.2.1. Terra Nullius and Native Title}

Terra nullius is an expression that refers to '.. a territory belonging to noone ...'. ${ }^{10}$ Originally, it was thought that land should be 'desert and uncultivated' in order to be deemed terra nullius. ${ }^{11}$ Over time it became evident that Australia was not terra nullius as per its original meaning, and as a result, several court decisions progressively broadened the definition of the concept seemingly to override Indigenous rights. ${ }^{12}$ The doctrine of terra nullius applied in Australia from 1788 until it was overturned in the High Court case of Mabov Queensland (No 2) (1992). ${ }^{13}$ Notably, the High Court held in this decision that upon colonisation the Crown gained '... a radical title to land ...', as opposed to absolute ownership, and the former does not preclude the existence of native

5 Northern Territory Law Reform Committee, Parliament of the Northern Territory, "Committee of Inquiry: Aboriginal Customary Law (Report, 2003)," https://justice.nt.gov.au/_data/assets/pdf_file/0011/238619/ntlrc_final_report.pdf, 13 para 4.2 .

${ }^{6}$ Ibid; McRae, op.cit., 75, 82, 92, 96, 117.

7 Northern Territory Law Reform Committee, loc.cit. Ruby Langford Ginibi, "Aboriginal Traditional and Customary Laws," Law Text Culture 1, (1994): 9.

8 Ginibi, loc.cit. Danial Kelly (i), "The Law of Sorcery in Madayin," ALJ 94, no. 1 (2020): 2 (forthcoming), citing George Pascoe Gaymarani, "An Introduction to the Ngarra Law of Arnhem Land," NTLJ 1, (2011): 296-297.

9 Ginibi, op.cit., 8. Danial Kelly (ii), "Foundational Sources and Purposes of Authority in Madayin," Victoria University Law and Justice Journal 4, no. 1 (2014): 40.

10 (Mabo v. Queensland (No 2)), Judgment, 175 Commonwealth Law Reports 1, 1992, p. 41 (Brennan J).

11 Gerry Simpson, "Mabo, International Law, Terra Nullius, and the Stories of Settlement: An Unresolved Jurisprudence," Melbourne University Law Review 19, no. 1 (1993): 199.

12 Ibid, 201-202.

13 (Mabo v. Queensland (No 2)), Judgment, 175 Commonwealth Law Reports 1, 1992, p. 180. Ashley M Foley, "Terra Nullius: The Aborigines in Australia" (Thesis submission, Salve Regina University, 2009) https://digitalcommons.salve.edu/cgi/viewcontent.cgi?article=1033\&context=pell_theses, 5 . 
title. ${ }^{14}$ Furthermore, the High Court recognised native title under the common law where the native rights and interests held by the original inhabitants under their traditional laws have subsisted. ${ }^{15}$

In consequence of this decision, the Commonwealth legislature passed the Native Title Act 1993 (Cth). ${ }^{16}$ This legislation enables native title claimants to make an application to the Federal Court for a decision on whether the claimant has recognisable native title rights. ${ }^{17}$ Native title are rights and interests which derive from Indigenous law and may be '... communal, group or individual rights and interests of Aboriginal peoples or Torres Strait Islanders in relation to land or waters ...' such as the right to hunt, fish or collect food. ${ }^{18}$

Findings have been made about the extent of native title recognition by reference to the Act in several Commonwealth court cases. ${ }^{19}$ In the Croker Island case,$^{20}$ the High Court held that native title in relation to seas, including '... rights and interests in respect of the sea-bed and subsoil beyond low-water mark and the waters above that sea-bed ...' are recognisable under the common law. ${ }^{21}$ However, 'exclusive' native title rights and interests in relation to the sea cannot be recognised because recognition would create a conflict with concurrent 'public and international rights'. ${ }^{22}$ Furthermore, in the case of Western Australia $v$ Ward, the High Court held that native title protection under the Act does not extend to 'cultural knowledge'. ${ }^{23}$ In this case, the High Court also explained how native title rights can be impacted or extinguished. ${ }^{24}$

In the case of Narrier $v$ State of Western Australia, ${ }^{25}$ the Federal Court recognised the '... right to access and take resources for any purpose, including

14 (Mabo v. Queensland (No 2)), Judgment, 175 Commonwealth Law Reports 1, 1992, p. 180, p. 53, 69 (Brennan J).

15 Ibid, p. 55, 68-69 (Brennan J). (Love v. Commonwealth of Australia; Thoms v. Commonwealth of Australia), Judgment, Australian Law Journal Reports 198, 2020, p. 210 para 34 (Kiefel CJ).

16 Native Title Act 1993 (Cth), s 3.

17 Ibid, ss 3, 4(7).

18 Ibid, ss 223(1)-(2).

19 (Commonwealth of Australia v. Yarmirr), Judgment, 208 Commonwealth Law Reports 1, 2001. (Western Australia v. Ward), Judgment, 213 Commonwealth Law Reports 1, 2002. (Narrier v. State of Western Australia), Judgment, Federal Court of Australia 1519, 2016. $1,2001$.

20 (Commonwealth of Australia v. Yarmirr), Judgment, 208 Commonwealth Law Reports

$21 \mathrm{Ibid}$, p. 37 para 8 (Gleeson CJ, Gaudron, Gummow and Hayne JJ).

22 Ibid, p. 68 paras 98-100 (Gleeson CJ, Gaudron, Gummow and Hayne JJ). Jackie Morris, "Sea Country - The Croker Island: Commonwealth of Australia v Yarmirr," Indigenous Law Bulletin 5, no. 14 (2002): 20.

23 (Western Australia v. Ward), Judgment, 213 Commonwealth Law Reports 1, 2002, p. 209 para 468 (Gleeson CJ, Gaudron, Gummow and Hayne JJ).

${ }^{24}$ Ibid, p. 208-212 para 468 (Gleeson CJ, Gaudron, Gummow and Hayne JJ). 2016.

25 (Narrier v. State of Western Australia), Judgment, Federal Court of Australia 1519, 
commercial purposes ...' as a native title right. ${ }^{26}$ In a recent High Court decision Justice Edelman stated: 'The powerful spiritual and cultural connection that Aboriginal people have with the land ... is, by definition, a powerful spiritual and cultural connection with the defined territory of Australia. ${ }^{27}$ However, despite this recognised connection to land, which raises questions about the right to sovereignty, two key points relating to nonrecognition were reinforced in this decision. ${ }^{28}$ Firstly, Kiefel CJ noted that the common law does not '... recognise traditional laws and customs as having force or effect in Australia'.29 And secondly, Gageler $\mathrm{J}$ confirmed that Australian case law does not recognise the sovereignty of Aboriginal groups. ${ }^{30}$

\subsubsection{Land}

Several pieces of Commonwealth legislation recognise Aboriginal land rights. ${ }^{31}$ The Aboriginal Land Rights (Northern Territory) Act 1976 (Cth) ('ALRA') has enabled Aboriginal groups to acquire inalienable freehold estates over lands that were owned under Aboriginal law. ${ }^{32}$ These estates are vested in Aboriginal land trusts which are administered by Aboriginal land councils. ${ }^{33}$ Vacant or unalienated Crown land of the Northern Territory could be claimed from the 1970s until 5 June 1997. ${ }^{34}$ Data from 2016 shows that approximately 44 percent of Northern Territory land is Aboriginal land. ${ }^{35}$ Section 74 of the ALRA confers on Aboriginal groups the right '... to enter upon Aboriginal land and use or occupy that land ...' in a manner authorised by 'Aboriginal tradition'. ${ }^{36}$ It is noteworthy to mention that there is a significant difference between the ALRA and native title. ${ }^{37}$ Under the former, the $A L R A$ grants land to

${ }^{26}$ Ibid, p. 18 para 32 (Mortimer J).

27 (Love v. Commonwealth of Australia; Thoms v. Commonwealth of Australia), Judgment, Australian Law Journal Reports 198, 2020, p. 288 para 450 (Edelman J).

28 Ibid, p. 223 para 102 (Gageler J), p. 210 para 37 (Kiefel CJ).

29 Ibid, p. 210 para 37 (Kiefel CJ).

30 Ibid, p. 223 para 102 (Gageler J).

31 Aboriginal Land Rights (Northern Territory) Act 1976 (Cth). Aboriginal Land Grant (Jervis Bay Territory) Act 1986 (Cth). Aboriginal Land (Lake Condah and Framlingham Forest) Act 1987 (Cth). Aboriginal and Torres Strait Islander Act 2005 (Cth).

32 Aboriginal and Torres Strait Islander Social Justice Commissioner, "Native Title

Report $2005 \quad$ Report, 2005,"
https://www.humanrights.gov.au/sites/default/files/content/social_justice/nt_report/ntrepor t05/pdf/NativeTitleReport2005.pdf, 51-52. Aboriginal Land Rights (Northern Territory) Act 1976 (Cth), ss 4, 5.

33 Aboriginal Land Rights (Northern Territory) Act 1976 (Cth), ss 4, 5.

34 Melinda Schroeder, "Northern Territory Law Handbook: Aboriginal Land, Native Title and Heritage," http://ntlawhandbook.org/foswiki/NTLawHbk/AboriginalLandNativeTitleAndHeritage, para 7.

35 Ibid.

${ }^{36}$ Aboriginal Land Rights (Northern Territory) Act 1976 (Cth), ss 71(1), 3 definition of 'Aboriginal tradition'.

37 Ibid, s 12; (Mabo v. Queensland (No 2)), Judgment, 175 Commonwealth Law Reports 1, 1992, p. 59-60. 
the traditional owners, whereas under the latter, rights and interests in land stem from Aboriginal law, and are safeguarded under Commonwealth law. ${ }^{38}$

Under the Aboriginal Land Grant (Jervis Bay Territory) Act 1986 (Cth), ownership of the majority of the Jervis Bay Territory is vested in the Wreck Bay Aboriginal Community Council, and notably, the Council is empowered to make a range of by-laws including law that reflects Aboriginal law. ${ }^{39}$ Furthermore, the land has been granted to Aboriginal corporations under the Aboriginal Land (Lake Condah and Framlingham Forest) Act 1987 (Cth). ${ }^{40}$ Under the Aboriginal and Torres Strait Islander Act 2005 (Cth), it is the role of the Indigenous Land and Sea Corporation to help Aboriginal corporations attain land and water rights and interests. ${ }^{41}$

\subsubsection{Cultural Heritage}

Various pieces of legislation recognise Aboriginal cultural heritage rights in respect of sites and objects. ${ }^{42}$ Under the Aboriginal and Torres Strait Islander Heritage Protection Act 1984 (Cth) the Minister is empowered to make legally binding declarations for the purpose of prohibiting harmful actions on Australian land, waters, or objects that are of Aboriginal cultural importance in circumstances where the relevant State or Territory has not taken sufficient protection measures. ${ }^{43}$ In addition, the Protection of Movable Cultural Heritage Act 1986 (Cth) is designed to prevent unauthorised exportation of '... objects that are of importance to Australia ...' including those which derive from Aboriginal culture. 44 And the Environment Protection and Biodiversity Conservation Act 1999 (Cth) recognises Indigenous cultural heritage rights by enabling places of significance under Indigenous tradition to be included on the national heritage register. ${ }^{45}$ The Act also permits Indigenous Australians to practice some kinds of traditional activities on Commonwealth reserves. ${ }^{46}$

38 (Love v. Commonwealth of Australia; Thoms v. Commonwealth of Australia), Judgment, Australian Law Journal Reports 198, 2020, p. 210 para 34 (Kiefel CJ). Aboriginal Land Rights (Northern Territory) Act 1976 (Cth), s 12. (Mabo v. Queensland (No 2)), Judgment, 175 Commonwealth Law Reports 1, 1992, p. 59.

39 Aboriginal Land Grant (Jervis Bay Territory) Act 1986 (Cth), ss 6, 8, 52A. McRae, op.cit., 272 para 5.610.

40 McRae, op.cit., 270-271 para 5.600.

41 Aboriginal and Torres Strait Islander Act 2005 (Cth), s 191D.

42 Aboriginal and Torres Strait Islander Heritage Protection Act 1984 (Cth). Protection of Movable Cultural Heritage Act 1986 (Cth). Environment Protection and Biodiversity Conservation Act 1999 (Cth).

43 Aboriginal and Torres Strait Islander Heritage Protection Act 1984 (Cth), ss 4, 9, 10, 13. McRae, op.cit., 420 para 8.370.

44 Protection of Movable Cultural Heritage Act 1986 (Cth), ss 7(1), 9.

45 Environment Protection and Biodiversity Conservation Act 1999 (Cth), s 324D. Environment Protection and Biodiversity Conservation Regulations 2000 (Cth), reg 10.01A(2)(i).

46 Environment Protection and Biodiversity Conservation Act 1999 (Cth), s 359A. 


\subsubsection{Evidence Law}

Under the Evidence Act 1995 (Cth), hearsay and opinions are inadmissible as evidence unless an exception applies on the basis that statements of this kind can be unreliable. In relation to exceptions involving ACL, the Act provides that the hearsay rule and the opinion rule do not preclude the admission of evidence concerning Indigenous 'traditional laws and customs'. ${ }^{47}$ The expression 'traditional laws and customs' is defined under the Act as including the '... traditions, customary laws, customs, observances, practices, knowledge, and beliefs of the group'. ${ }^{48}$ The rationale underlying each of the exceptions is to facilitate the admission of evidence about Indigenous traditional laws and customs'. ${ }^{49}$ This is because the legislature recognises that the hearsay rule and the opinion rule can unfairly clash with the unique nature of ACL.50 For example, acquiring knowledge of ACL necessarily involves hearsay. ${ }^{51}$ This is because such knowledge is generally transmitted from generation to generation via unwritten modes such as dance, and oral communication. ${ }^{52}$ Therefore, it is usually not possible to understand the content of ACL from the original legal source.

\subsubsection{Family Law}

The Family Law Act 1975 (Cth) recognises many aspects of Aboriginal tradition including cultural rights, kinship systems, and customs associated with caring for children. ${ }^{53}$ For example, where a parenting order is sought under Part VII in relation to a child of Indigenous descent, the court must decide whether the order proposed is in the 'best interests of the child' by considering various cultural matters, such as the right to experience Indigenous cultural heritage. ${ }^{54}$ Furthermore, the court is required to '... have regard to any kinship obligations, and child-rearing practices ...'.55 These examples within the Act and other Commonwealth instruments previously referred to demonstrate that many aspects of ACL can function harmoniously alongside Australian law. However, fragmented forms of recognition at the will of the dominant governing polity do not resolve the issue of recognition to the fullest extent that is possible. Broader recognition is needed through a more meaningful legal avenue such as in a treaty.

\footnotetext{
47 Evidence Act 1995 (Cth), ss 72, 78A.

48 Ibid, Dictionary Part 1 'traditional laws and customs'.

49 (Mehmet v. Carter), Judgment, NSWSC 413, 2020, para 249 (Ward CJ).

50 Ibid.

${ }^{51}$ Ibid.

52 Ibid; Ginibi, loc.cit.

${ }^{53}$ Family Law Act 1975 (Cth), ss 60CC(3)(h), (6), 60B(3), 61F.

${ }^{54}$ Ibid, ss 60CC(3)(h), (6), 60B(3).

55 Ibid, s $61 \mathrm{~F}$.
} 


\subsubsection{Crime}

In the High Court case of Walker $v$ New South Wales, ${ }^{56}$ Mason CJ stated that Aboriginal criminal law '... was extinguished by the passage of criminal statutes of general application'.57 This essentially means that Aboriginal criminal law does not have legal force in Australia. ${ }^{58}$ In addition, when a Northern Territory or Federal court is in the process of deciding a sentence and various other types of determinations, the Crimes Act 1914 (Cth) limits the way that ACL can be taken into account. 59 It does this by prohibiting such courts from considering '.. any form of customary law or cultural practice ...'60 as a factor that diminishes or increases the severity of both criminal conduct and alleged criminal conduct. ${ }^{61}$ In other words, these restrictions preclude ACL from being acknowledged for the aforementioned purposes in criminal matters. ${ }^{62}$ However, case law in the Northern Territory suggests that it can be permissible for courts to consider custom and culture for other reasons. ${ }^{63}$ It is noteworthy to mention that the provisions can cause unjust judicial outcomes because an objectively right decision cannot be reached without consideration of all relevant factors. ${ }^{64}$

\subsubsection{Summary of Findings}

Part 2.1.2. demonstrates several facts about the extent that Commonwealth law recognises ACL. Firstly, Commonwealth law generally recognises the existence of ACL. 65 Secondly, Commonwealth law does not formally recognise that Aboriginal legal systems coexist with the Australian

56 (Walker v. New South Wales), Judgment, 182 Commonwealth Law Reports 45, 1994.

57 Ibid, p. 50 (Mason CJ).

58 Ibid.

(b).

59 Crimes Act 1914 (Cth), ss 15AB(1)(b)(i)-(ii), 16A(2A)(a)-(b), 16AA(1)(a)-(b), 19B(1A)(a)-

60 Ibid, ss 19B(1A)(a)-(b).

61 Ibid, ss 15AB(1)(b)(i)-(ii), 16A(2A)(a)-(b), 16AA(1)(a)-(b), 19B(1A)(a)-(b). (The Queen v. Wunungmurra), Judgment, Northern Territory Supreme Court 24, 2009, p. 9 para 22 (Southwood J).

62 Crimes Act 1914 (Cth), ss 15AB(1)(b)(i)-(ii), 16A(2A)(a)-(b), 16AA(1)(a)-(b), 19B(1A)(a)(b).

63 (The Queen v. Wunungmurra), Judgment, Northern Territory Supreme Court 24, 2009, p. 12-13 para 29 (Southwood J).

64 Ibid, 11 para 25.

65 Aboriginal Land Rights (Northern Territory) Act 1976 (Cth). Aboriginal Land Grant (Jervis Bay Territory) Act 1986 (Cth). Aboriginal Land (Lake Condah and Framlingham Forest) Act 1987 (Cth). Aboriginal and Torres Strait Islander Act 2005 (Cth). Family Law Act 1975 (Cth), ss 60CC(3)(h), (6), 60B(3), 61F. Aboriginal and Torres Strait Islander Heritage Protection Act 1984 (Cth). Protection of Movable Cultural Heritage Act 1986 (Cth). Environment Protection and Biodiversity Conservation Act 1999 (Cth). Evidence Act 1995 (Cth), s 72. Native Title Act 1993 (Cth). 
legal system or Aboriginal sovereignty. ${ }^{66}$ Thirdly, Commonwealth law gives force to portions of ACL by adopting it within the legislation. ${ }^{67}$ Fourthly, Commonwealth law will not give force to ACL where the latter clashes with the former. ${ }^{68}$ And fifthly, the Common law does not regard ACL as having any '... force or effect in Australia'. ${ }^{69}$ Thus, it is evident that Commonwealth law recognises ACL to a limited extent. ${ }^{70}$

\subsection{The Impact of Australian Law and Criminal Justice Issues}

Part 2.2. examines examples of how Australian law impacts the lives of Indigenous Australians, and why Indigenous Australians are over-represented in the criminal justice system. ${ }^{71}$ Research in this area is important because it can be used to ascertain how the law can be improved to promote wellbeing in the lives of Indigenous Australians. It is ultimately found that Australian law impacts how Indigenous Australians experience traditional life. ${ }^{72}$ It is also found that Indigenous Australians are over-represented in the criminal justice system because the Australian legal system has created conditions in Indigenous life that lessen the personal 'cost' of committing a crime. ${ }^{73}$ The sections that follow discuss the reasons in support of these findings.

\subsubsection{The Impact of Australian Law}

In Indigenous tradition, customary law is a guiding source of authority in relation to significant life matters such as how to maintain societal order, rights and obligations, spirituality, purpose, and individual identity. ${ }^{74}$ Australian law impacts how Indigenous Australians experience life under

66 McRae, op.cit., 66 para 2.10. (Love v. Commonwealth of Australia; Thoms v. Commonwealth of Australia), Judgment, Australian Law Journal Reports 198, 2020, p. 223 para 102 (Gageler J).

67 McRae, op.cit., 114 para 2.520.

68 (Walker v. New South Wales), Judgment, 182 Commonwealth Law Reports 45, 1994, p. 50 (Mason CJ).

69 (Love v. Commonwealth of Australia; Thoms v. Commonwealth of Australia), Judgment, Australian Law Journal Reports 198, 2020, p. 210 para 37 (Kiefel CJ).

70 McRae, op.cit., 111-112 para 2.470, 114 para 2.520.

71 Melanie Schwartz, "Redressing Indigenous Over-Representation in the Criminal Justice System with Justice Reinvestment," Precedent (Sydney, N.S.W.), no. 118 (2013): 39.

72 McRae, op.cit., 66 para 2.10. Criminal Code Act 1983 (NT), ss 134, 188, 127, 131A, 192. Marriage Act 1961 (Cth), ss 94, 95. Danial Kelly (iii), "Marriage Law in Madayin," Australian Law Journal 88, no. 8 (2014): 536-539.

73 Diego Gambetta. Codes of the Underworld: How Criminals Communicate (New Jersey, Princeton University Press, 2009), 8-9. (Love v. Commonwealth of Australia; Thoms v. Commonwealth of Australia), Judgment, Australian Law Journal Reports 198, 2020, p. 226 para 121 (Gageler J). (Milirrpum v. Nabalco Pty Ltd), Judgment, 17 Federal Law Reports 141, 1971, p. 267 (Blackburn J); McRae, loc.cit.

74 Northern Territory Law Reform Committee, op.cit., 13 para 4.4. McRae, op.cit., 74 para 2.130. (Milirrpum v. Nabalco Pty Ltd), Judgment, 17 Federal Law Reports 141, 1971, p. 267 (Blackburn J). 
customary law in several ways. Firstly, Australian law overrides and removes the legal force of customary law without the consent of Indigenous Australians. 75 Secondly, Australian law only recognises limited aspects of customary law. ${ }^{76}$ And thirdly, Australian law expressly refuses to recognise ACL in some instances. ${ }^{77}$ By undermining customary law in these ways, Australian law has suppressed the role of customary law within Indigenous life, and in doing so, it has caused great loss. ${ }^{78}$

In addition, Australian law impacts the lives of Indigenous Australians by prohibiting and punishing forms of conduct that are lawful under ACL. ${ }^{79}$ For example, the Yolngu people of Arnhem Land adhere to the Madayin system of law. 80 Australian law forbids many types of conduct that can, in specific circumstances, be authorised under Madayin law. ${ }^{81}$ For example, incestuous sexual intercourse and forced sexual intercourse can be obligatory during the 'Kunapipi ceremony' which is a ritual that is conducted for the purpose of ensuring the fertility of humankind. ${ }^{82}$ In addition, mandatory sexual intercourse can be imposed as a punishment for misconduct, polygyny is permissible, and physical discipline can be authorised in response to a violation of marriage law. ${ }^{83}$ Furthermore, in the promised marriage system, a girl can engage in a sexual relationship with her husband from the time that she has completed sexual development. 84 The moral considerations do not negate the fact that Australian law impacts the practice of Madayin law.

\subsubsection{Over-representation in the Criminal Justice System}

Data shows that Indigenous Australians have been over-represented in the criminal justice system for many decades, and this problem remains an issue to be resolved. 85 Over-representation in this context relates to incarceration and many areas where Indigenous Australians interact with the

75 (Love v. Commonwealth of Australia; Thoms v. Commonwealth of Australia), Judgment, Australian Law Journal Reports 198, 2020, para 37 (Kiefel CJ). McRae, op.cit., 66 para 2.10.

76 McRae, op.cit., 114-115, 117.

77 (Walker v. New South Wales), Judgment, 182 Commonwealth Law Reports 45, 1994, p. 50 (Mason CJ).

78 McRae, op.cit., 66 para 2.10.

79 Criminal Code Act 1983 (NT), ss 134, 188, 127, 131A, 192. Marriage Act 1961 (Cth), ss $94,95$.

80 Kelly (ii), op.cit., 33.

81 Criminal Code Act 1983 (NT), ss 134, 188, 127, 131A, 192. Marriage Act 1961 (Cth), ss 94, 95. Kelly (iii), loc.cit.

82 Kelly (iii), op.cit., 538.

83 Ibid, 536-539.

84 Ibid, 537.

85 Rebecca Wallis and April Chrzanowski, "Addressing Indigenous Over-Representation in the Australian Criminal Justice System: Some Thoughts about the Role of Legal Institutions as Stewards of a Complex System," Pandora's Box (2015): 37-38. 
criminal justice system. 86 For example, Schwartz notes that overrepresentation occurs '.. in the areas of police discretion in regard to diversion, cautioning, arresting and charging, through to bail decisions ...' 87 Furthermore, data from numerous Australian jurisdictions shows that Indigenous Australians represent a high proportion of victims of violent offences. ${ }^{88}$

People avoid crime if the personal 'cost' of committing crime is too great. 89 The expression 'personal cost' is intended to refer to the personal consequences that flow from criminal conduct. 90 Generally, the commission of an offence is of great personal 'cost' if a person is valued, and if a person is carrying out meaningful life purposes. ${ }^{91}$ An argument can be made that these two elements present obstacles for some Indigenous Australians, that are unique to Indigenous life, because of Australian law. ${ }^{92}$ This will now be illustrated with examples.

\subsubsection{Value and Contrition}

The over-representation of Indigenous Australians in the criminal justice system is in part due to the fact that the personal 'cost' of committing a crime is less where a person has been made to feel unvalued by a historically oppressive legal system. ${ }^{93}$ Similarly, the personal 'cost' is low when a person harbours enmity toward the government authorities due to past and present injustices. ${ }^{94}$ Countless examples can be found in Australian history of harmful government action against Indigenous people such as mass killings, dispossession of land, and racist and discriminatory laws, all of which would give rise to feelings of enmity in the victims towards the government. 95 Every harmful government action of the past and present conveys to Indigenous Australians that they are not of value in Australian society. ${ }^{96}$ If meaningful

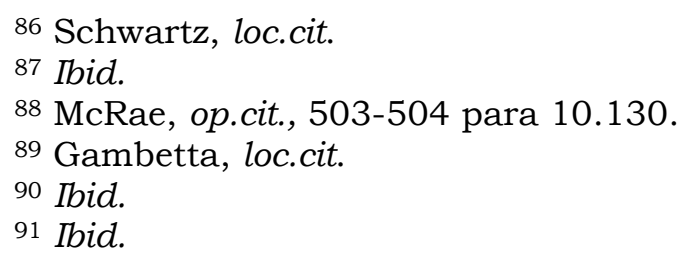
Judgment, Australian Law Journal Reports 198, 2020, p. 226 para 121 (Gageler J). (Milirrpum v. Nabalco Pty Ltd), Judgment, 17 Federal Law Reports 141, 1971, p. 267 (Blackburn J). McRae, op.cit., 66 para 2.10.

93 Gambetta, loc.cit. McRae, op.cit., 16 para 1.110, 21 para 1.220, 27 para 1.320.

94 Gambetta, loc.cit. McRae, loc.cit.

95 (Love v. Commonwealth of Australia; Thoms v. Commonwealth of Australia), Judgment, Australian Law Journal Reports 198, 2020, p. 226 para 121 (Gageler J). McRae, loc.cit.

96 (Love v. Commonwealth of Australia; Thoms v. Commonwealth of Australia), Judgment, Australian Law Journal Reports 198, 2020, p. 226 para 121 (Gageler J). 
action through law reform is taken to demonstrate contrition, and the value of Indigenous Australians, then Indigenous Australians will be more likely to form a positive outlook on Australian society. ${ }^{97}$ And if a positive outlook is formed, the personal 'cost' of committing a crime will become higher. ${ }^{98}$

\subsubsection{Life Purposes}

The over-representation of Indigenous Australians in the criminal justice system also partially stems from the fact that the personal 'cost' of committing a crime is low when a person is unable to live out their life purposes. ${ }^{99}$ For example, some Indigenous Australians are living under conditions of extreme disadvantage, and this may prevent them from fulfilling their goals in life. ${ }^{100}$ These conditions can include '[p]overty, unemployment, low levels of education, and lack of access to social services .... ${ }^{101}$ Indigenous customary law created living conditions that met the needs of Indigenous peoples for thousands of years. ${ }^{102}$ Colonial law and the Australian legal system intruded on this arrangement and diminished its effectiveness. ${ }^{103}$ If the aforementioned social problems, and the weakening of customary law, can be more successfully addressed, then Indigenous Australians will be more empowered to carry out their life purposes. ${ }^{104}$ And when a person is carrying out their life purposes, the personal 'cost' of committing a crime is higher than what it would be in a person that is not doing the same. ${ }^{105}$

\subsubsection{Summary of Findings}

Australian law impacts the way that Indigenous Australians experience traditional life. ${ }^{106}$ It does this by significantly replacing and opposing ACL, and by prohibiting and penalising forms of conduct that are lawful under ACL. ${ }^{107}$

97 Ibid.

98 Gambetta, loc. cit.

99 Schwartz, loc.cit. Gambetta, loc.cit.

100 Productivity Commission for the Steering Committee for the Review of Government Service Provision, "Overcoming Indigenous Disadvantage Report, 2016," https://www.pc.gov.au/research/ongoing/overcoming-indigenous-disadvantage/2016/reportdocuments/oid-2016-overcoming-indigenous-disadvantage-key-indicators-2016-report.pdf, Chapter 1, 4.

101 Ibid, Chapter 4, 3.

102 (Milirrpum v. Nabalco Pty Ltd), Judgment, 17 Federal Law Reports 141, 1971, p. 267

(Blackburn J). Northern Territory Law Reform Committee, op.cit., 13 para 4.3.

103 McRae, op.cit., 66 para 2.10.

104 Ibid.

105 Gambetta, loc.cit.

106 McRae, loc.cit. Criminal Code Act 1983 (NT), ss 134, 188, 127, 131A, 192. Marriage Act 1961 (Cth), ss 94, 95. Kelly (iii), op.cit., 536-539.

107 (Love v. Commonwealth of Australia; Thoms v. Commonwealth of Australia), Judgment, Australian Law Journal Reports 198, 2020, p. 223 para 102 (Gageler J). McRae, loc.cit. Criminal Code Act 1983 (NT), ss 134, 188, 127, 131A, 192. Marriage Act 1961 (Cth), ss 94, 95. Kelly (iii), loc.cit. 
The over-representation of Indigenous Australians in the criminal justice system is at least in part due to the Australian legal system. ${ }^{108}$ Customary law provided living conditions that served Indigenous peoples for millennia, and this state of affairs was undermined by the imposition of colonial law and the Australian legal system. ${ }^{109}$ Furthermore, it was undermined by a long history of harmful government action. 110 These past actions have created conditions within Indigenous life today that can have the effect of lessening the personal 'cost' of committing a crime. ${ }^{111}$

\subsection{Improving Indigenous Property Rights}

The present state of Indigenous legal rights in Australia is inadequate on account of numerous reasons. ${ }^{112}$ It is necessary to further develop Indigenous legal rights in order to reduce injustice and to enhance the wellbeing of Indigenous Australians. To assist in achieving these objectives, Part 2.3. argues that Indigenous property rights have not progressed to an adequate extent partially due to the limitations of the Native Title Act 1993 (Cth) ('the Act'), and communally owned Indigenous land rights. ${ }^{113}$ These arguments will be demonstrated by discussing how the native title system has the capacity to disqualify valid native title claims, and how the communal Indigenous land system generally does not economically benefit individuals. ${ }^{114}$

\subsubsection{Native Title}

In the process of making a native title claim the applicant must prove that they hold native title within the meaning that it is given under section 223(1) of the Act. ${ }^{115}$ Aboriginal and Torres Strait Islander peoples can face

108 Gambetta, loc.cit. (Love v. Commonwealth of Australia; Thoms v. Commonwealth of Australia), Judgment, Australian Law Journal Reports 198, 2020, p. 226 para 121 (Gageler J). (Milirrpum v. Nabalco Pty Ltd), Judgment, 17 Federal Law Reports 141, 1971, p. 267 (Blackburn J). McRae, loc.cit.

109 (Milirrpum v. Nabalco Pty Ltd), Judgment, 17 Federal Law Reports 141, 1971, p. 267

(Blackburn J). Northern Territory Law Reform Committee, loc.cit. McRae, loc.cit.

110 McRae, op.cit., 16 para $1.110,21$ para $1.220,27$ para 1.320.

111 Gambetta, loc.cit.

112 Garth Nettheim, "Developing Aboriginal Rights," Victoria University of Wellington Law Review 19, no. 4 (1989): 407.

113 Australian Law Reform Commission (ii), "Connection to Country: Review of the Native Title Act 1993 (Cth) Report No 126, April 2015," https://www.alrc.gov.au/wpcontent/uploads/2019/08/alrc_126_final_report.pdf, 17-19. Helen Hughes, Mark Hughes, and Sara Hudson, "Private Housing on Indigenous Lands Report, 2010," https://www.cis.org.au/app/uploads/2015/07/pm113.pdf, 1-2.

114 Australian Law Reform Commission (ii), loc.cit. Helen Hughes, Mark Hughes, and Sara Hudson, loc.cit.

115 Native Title Act 1993 (Cth), s 223(1). 
many impediments when attempting to fulfil the definitional criteria. ${ }^{116}$ For example, under section 223(1) of the Act, claimants are required to demonstrate that the laws and customs giving rise to the native title rights are 'traditional' in nature.117 Under the present law, several requirements are incorporated into the term 'traditional'. 118 These include: (1) each generation has transmitted the laws and customs to the following generation; (2) the laws and customs predate the arrival of the British to this continent; and (3) the laws and customs have operated in a 'continuous' manner from the moment in time that this continent became a dominion of the British Crown. ${ }^{119}$

These strict requirements can create injustice by disqualifying legitimate native title claims. ${ }^{120}$ For example, Wootten states in relation to this: 'Ironically, the more injustice a community has suffered in the way of dispossession, forced movement and institutionalisation, and suppression of its traditional culture, the less chance it will have of establishing title.'121 In essence, the requirements that must be satisfied in order to fulfil the definition of 'tradition' are unjust given that loss of tradition has predominantly occurred due to the actions of Australian governments. ${ }^{122}$ Furthermore, the criteria preclude the protection of native title where the laws and customs have changed since the arrival of the British. ${ }^{123}$ This is also problematic given that law inevitably transforms in accordance with changing societal norms, values and conditions. ${ }^{124}$

The Australian Law Reform Commission ('ALRC') has suggested that several native title reforms be implemented in order to improve the native title system, and to facilitate accomplishing the objectives of the Act which concern giving life to native title rights. ${ }^{125}$ For example, it has suggested that a statement be inserted into the Act which recognises '... that traditional laws and customs under which native title rights and interests are possessed may adapt, evolve or otherwise develop'. ${ }^{126}$ Furthermore, the ALRC has suggested that a statement be inserted into the Act which recognises that there is no need to establish that the laws and customs have operated '... substantially uninterrupted since sovereignty ...' ${ }^{127}$ And the ALRC has suggested that a statement be included in the Act which recognises that there is no need to

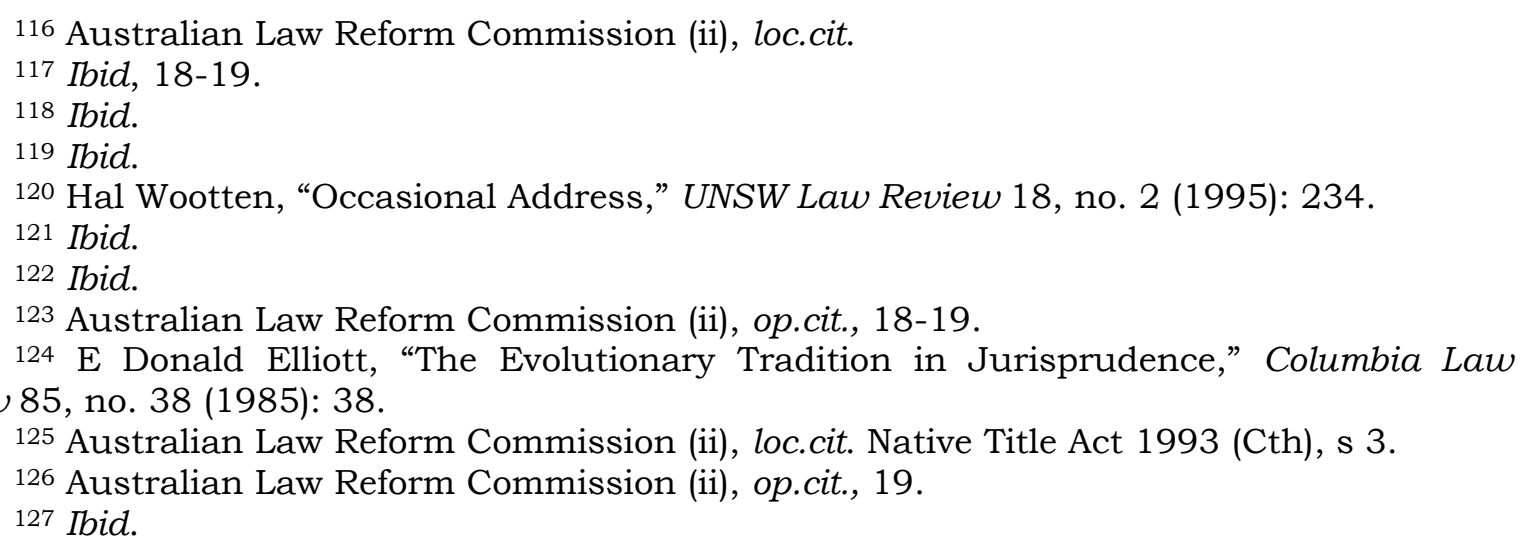


prove that an Indigenous group has subsisted and practiced the laws of their legal system in a unified manner from a time which predates this continent becoming a dominion of the British Crown. ${ }^{128}$ Such reforms would have the effect of furthering the purposes of the Act by enabling the success of a wider range of legitimate native title claims. ${ }^{129}$ Accordingly, these reforms need to be implemented in order to further develop native title rights. 130

\subsubsection{Private Indigenous Land Rights}

Prior to the colonial period, land was owned communally under traditional Indigenous laws. ${ }^{131}$ In recent decades, Australian governments have recreated communal ownership systems by granting vast amounts of land in Australia to the traditional Indigenous owners in the form of inalienable freehold communal title. ${ }^{132}$ Attempting to recreate the Indigenous communal system of ownership in its past form has arguably disadvantaged Indigenous people living on communal Indigenous lands significantly. ${ }^{133}$

To illustrate, Indigenous Australians living on communal Indigenous lands are experiencing some of the most terrible living conditions in Australia. ${ }^{134}$ Government solutions such as the provision of social housing and control over how welfare is spent do not address the heart of the issue. ${ }^{135}$ Namely, good living conditions partially derive from private ownership rights such as the right to privately own land, and the right to privately own a business. ${ }^{136}$ Indigenous landowners cannot own government-granted Indigenous land in a private capacity. ${ }^{137}$ As a result, they are precluded from enjoying the economic benefits that can be attained through private rights such as homeownership and prospering financially through businesses. ${ }^{138}$

Thus, when law reformers sought to give back land to the traditional Indigenous owners arguably the objective should not have been to recreate Indigenous ownership systems as close to the old form as possible. ${ }^{139}$ Instead, it should have been to create a system that gives life to the fundamental aspects of the old system while still enabling Indigenous peoples to progress in

128 Ibid.

129 Ibid. Native Title Act 1993 (Cth), s 3.

130 Australian Law Reform Commission (ii), op.cit., 18-19.

131 Leon Terrill, "The Days of the Failed Collective: Communal Ownership, Individual Ownership and Township Leasing in Aboriginal Communities in the Northern Territory," UNSW Law Journal 32, no. 3 (2009): 817.

132 Helen Hughes, Mark Hughes, and Sara Hudson, op.cit., 1-2, 4.

133 Ibid, 1-2.

134 Ibid, 1.

135 Ibid.

136 Ibid, 2.

137 Ibid, 1-2.

138 Ibid.

139 Ibid. 
the modern world. ${ }^{140}$ It is unjust that Indigenous Australians living on such lands must relocate from their traditional lands in order to purchase a home. ${ }^{141}$ And in any case, in most instances, relocating is impossible due to numerous barriers. ${ }^{142}$ This means that the people living on those lands are generally trapped in a cycle of disadvantage. ${ }^{143}$

In a report titled 'Private Housing on Indigenous Lands', the authors propose that Indigenous owners of traditional land should be able to attain private land ownership rights, as well as how this idea could be achieved whilst still preserving communal property rights. ${ }^{144}$ The recommendations made by the authors may face opposition due to the fact that preventing the land from being alienated ensures that the lands remain in the possession of the traditional owners, and it precludes predatory buyers from purchasing the land below the market value. However, while these protections are important, the prohibition is unjust on its own and requires exceptions. ${ }^{145}$

Enabling access to private land rights is not a radical idea because the system proposed is similar to how land rights function in the rest of Australian society. ${ }^{146}$ For example, certain areas of land are designated for private ownership such as residential areas, while other areas of land are designated for communal use, such as libraries and parks. ${ }^{147}$ Furthermore, the creation of private land rights on Indigenous lands would not amount to imposing Western economic values on Indigenous peoples. ${ }^{148}$ Research suggests that a large proportion of Indigenous traditional landowners support the idea of attaining private land rights. ${ }^{149}$ And this may be evidence of a new norm where increased value is being placed on individual economic progression within remote Indigenous communities. ${ }^{150}$ Accordingly, the present land rights of the traditional Indigenous landowners across Australia cannot be regarded as properly developed in the absence of private land rights. ${ }^{151}$

\subsubsection{Summary of Findings}

The native title system unfairly disqualifies legitimate native title claims through its rigid requirements. ${ }^{152}$ Native title claims should not be rejected on

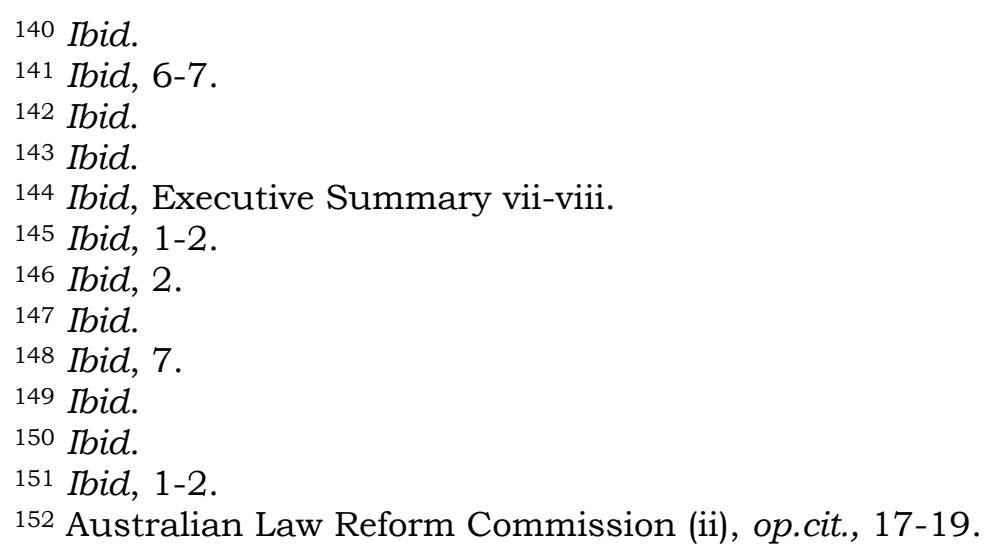


the ground that the Indigenous law or custom has altered since the time that this continent became the dominion of the British Crown. ${ }^{153}$ This is because law ordinarily transforms in order to adjust to changing social norms, values, and conditions. ${ }^{154}$ Furthermore, the concept of 'tradition' under the native title system must be understood more broadly in order to ensure that the injustices of the past do not prevent justice in the future. ${ }^{155}$

Private land rights may promote quality of life in that through such rights people can obtain the benefits that flow from homeownership, and people can prosper from the land by using it for business purposes. ${ }^{156}$ For these reasons, traditional Indigenous landowners must be able to attain private property rights on Indigenous lands so that they may have a greater opportunity to progress at an individual level.157 Accordingly, Indigenous property rights need to be developed in order to lessen injustice and to enhance the wellbeing of Indigenous Australians.

\subsection{The Value of a Comparative Law Perspective}

Indigenous legal issues ('ILIs') must be extensively understood in order to conscientiously assess the quality of proposed solutions. ${ }^{158}$ In the quest to obtain an extensive understanding of ILIs, comparative law may be required for two reasons. Firstly, ILIs can be challenging to understand exclusively through an Australian legal perspective because some issues are embedded in a uniquely Aboriginal cultural context that is surrounded by many conceptual barriers. ${ }^{159}$ And secondly, comparative lawyers can break through such barriers for the purpose of providing specialist insights about ILIs through the use of the 'law-in-context method'.160 To support these propositions, the sections that follow discuss: (1) comparative law theory; (2) how comparative law research could have broken cultural barriers thereby enabling increased insight about ILIs during the colonial period and beyond; and (3) how comparative law research can facilitate understanding of ILIs in contemporary Australian society. The examples provided in Part 2.4. are about issues which require a comparative law perspective due to their nature. It is not argued that all ILIs require understanding through comparative law.

\section{Ibid, 19.}

154 Elliott, loc.cit.

155 Australian Law Reform Commission (ii), op.cit., 19. Wootten, loc.cit.

156 Helen Hughes, Mark Hughes, and Hudson, loc.cit.

157 Ibid.

158 Christopher A Whytock, "Legal Origins, Functionalism, and the Future of Comparative Law," Brigham Young University Law Review, no. 6 (2009): 1879.

159 Edward J Eberle, "The Methodology of Comparative Law," Roger Williams University School of Law 16, no. 1 (2011): 52. Ronald Sackville, "Legal Protection of Indigenous Culture in Australia," Cardozo Journal of International and Comparative Law 11, no. 2 (2003): 714-15.

160 Mark Van Hoecke, "Methodology of Comparative Legal Research," Law and Method, no. 12 (2015): 16. 


\subsubsection{Comparative Law Theory}

Comparative law is a form of legal research that can be undertaken using a range of methodology, however, it generally entails: (1) comparing the 'similarities' and 'differences' between legal systems; (2) objectively analysing those findings; and (3) drawing conclusions. ${ }^{161}$ Comparing legal systems can serve many purposes including to gain a deeper understanding of ILIs. ${ }^{162}$ Research can be undertaken using an individual method or multiple methods, and comparative lawyers ascertain which methods should be used, and which legal systems should be compared, by considering the nature of the research subject matter, and the objective of the research. ${ }^{163}$

The application of a basic comparative method, which essentially involves comparing, and a variant of the 'law-in-context' method, can be used in conjunction to make significant findings about ILIs. ${ }^{164}$ The 'law-in-context' method referred to involves examining the 'legal culture' of a foreign society, or in other words, the contextual features that impact how the laws develop, in order to facilitate identifying, comprehending, and comparing, the laws under examination. 165 Eberle states that these features may include: '... religion, history, geography, morals, custom, philosophy or ideology, among other driving forces'. 166

\subsubsection{Understanding Indigenous Issues through Comparative Methods}

Comparative law research about Indigenous 'legal culture' on this continent and in other nations could have facilitated a greater understanding of ILIs during colonial times and beyond. ${ }^{167}$ This proposition can be illustrated by comparing common elements across Australian Indigenous legal systems and South American Indigenous legal systems. Firstly, under the aforementioned systems, the concepts of law, religion, and culture operate in a very amalgamated form. ${ }^{168}$ Secondly, social interactions are governed by a spiritual source in the legal systems of both Indigenous populations. ${ }^{169}$ Thirdly, South American Indigenous legal systems contain rules related to '.. communal and collective aspects of ownership ...', and Australian Indigenous legal systems similarly embrace such concepts. ${ }^{170}$ Fourthly, land or land

161 Hoecke, op.cit., 8. Eberle, op.cit., 52, 55, 57-8, 62.

162 Hoecke, op.cit., 2, 8.

$163 \mathrm{Ibid}$, paras 2, 1, 4.

164 Ibid, paras 4, 4.4.

165 Ibid, para 4.4. Eberle, op.cit., 52, 65.

166 Eberle, op.cit., 52.

$167 \mathrm{Ibid}, 52,65$.

168 Rodrigo Míguez Núñez, "Indigenous Customary Law in a Civil Law Context: Latin America and the Chilean Case," Rechtsgeschichte - Legal History, no. 24 (2016): 302-3. Sackville, loc.cit.

169 Núñez, op.cit., 302. Sackville, loc.cit.

170 Núñez, op.cit., 302-303. Terrill, loc.cit. 
features may be 'sacred' in both systems due to the mystical nature of the terrain. ${ }^{171}$ And fifthly, these systems provided social order, notwithstanding that the systems are different to common law legal systems in the following ways: (1) the philosophies of each Indigenous 'legal culture' are spiritual in nature, unlike Western legal philosophy such as legal positivism which is profane in nature; (2) Indigenous law is given its force by spiritual powers; (3) communal property rights are an important aspect of Indigenous property law; and (4) the rights to land or land features derive at least in part from a mystical relationship with the terrain. ${ }^{172}$

Thus, comparative law research could have shown that similar cultures can produce similar legal systems. ${ }^{173}$ Furthermore, it could have demonstrated that Australian Indigenous legal systems share a wide range of similarities with other Indigenous legal systems that have similar contextual features, and all systems achieve social order as well as other fundamental purposes. ${ }^{174}$ And since legal systems are designed to fulfil fundamental purposes particularly in relation to social order, these findings could have been used to conclude that such systems should be preserved notwithstanding that the dominant legal systems of the world differ significantly. ${ }^{175}$

In addition, if these findings had of been better understood during the colonial period and beyond through a comparative law perspective, then the following positive outcomes may have ensued: (1) this knowledge may have led to the adoption of formal legal pluralism when colonisation began; (2) every legal system on this continent may have been preserved, while gradually evolving in a way that aligned with human rights principles; (3) treaties may have been agreed to, and land may have been exchanged through negotiation and payment, rather than by force; (4) there may have been less discriminatory and racist law that applied to Indigenous people; and (5) there may have been less arbitrary killings of Indigenous people. ${ }^{176}$ Accordingly, these findings and conclusions demonstrate that a comparative law perspective can be required when in the process of seeking to understand and resolve ILIs.

171 Núñez, loc.cit. Sackville, loc.cit.

172 Núñez, loc.cit. Sackville, loc.cit. Terrill, loc.cit.

Kenny Yang, "The Rise of Legal Positivism in Germany: A Prelude to Nazi Arbitrariness?" Western Australian Jurist 3, no. 9 (2012): 245-6.

173 Sackville, loc.cit. Núñez, loc.cit. Eberle, loc.cit.

174 Sackville, loc.cit. Núñez, loc.cit. Eberle, loc.cit. Legal Monitor Worldwide, "I Want the True Law that Brings Peace and Harmony: Five Questions for Dianne Biritjalawuy Gondarra," https: / /cdu-edu-

primo.hosted.exlibrisgroup.com/permalink/f/7r169d/TN_gale_ofg388105271, para 9.

175 Marshall Cohen, "Law, Morality and Purpose," Villanova Law Review 10, no. 4 (1965): 647. Legal Monitor Worldwide, loc.cit.

176 McRae, op.cit., Chapter 1. 
Comparative law research can also be required when seeking to understand ILIs in contemporary society. For example, comparative law can be used to: (1) compare the 'legal culture' of Australian Indigenous legal systems with the Australian legal system such as by exploring philosophies and the meaning of key terms; (2) ascertain and compare the legal rules of Australian Indigenous legal systems and the Australian legal system; and (3) identify where Australian Indigenous law either conflicts with, or operates in harmony with, Australian law or international legal principles. ${ }^{177}$ Furthermore, an analysis of such findings can then be used for two key purposes related to ILIs. The first is to obtain an extensive understanding of culturally complex ILIs. ${ }^{178}$ And the second is to draw conclusions on ways of resolving ILIs. ${ }^{179}$

Insight about Australian ILIs can also be gained through comparative law research about the legal problems experienced by Indigenous peoples in other nations. ${ }^{180}$ To illustrate, research suggests that compelling Indigenous peoples to assimilate inevitably leads to significant social problems. ${ }^{181}$ For example, in both Australia and Canada, removing Aboriginal children from their communities and placing them in appallingly managed residential schools, in order to assimilate them, has profoundly impacted those children and their descendants across many generations. ${ }^{182}$ Some of these impacts include engaging in criminal conduct, mental health issues, loss of family relationships and tribal networks, disconnection with cultural heritage, and decreased use of Indigenous languages. ${ }^{183}$

The similarity between the impacts experienced by Indigenous Australians and Indigenous Canadians is a factor that strongly demonstrates that compelled assimilation contributes to social problems. ${ }^{184}$ Thus, this comparative law research provides insight about how past assimilation laws and policies in each nation were immeasurably harmful. 185 This finding can be used to draw conclusions about how future law and policy related to assimilation and Indigenous peoples should be shaped. ${ }^{186}$ In addition, comparative law research can be used to compare how each nation has attempted to alleviate the impacts of compelled assimilation in order to

177 Eberle, op.cit., 55-6, 64.

H C Gutteridge, "Comparative Law and the Conflict of Laws," Transactions of the Grotius Society (Cambridge University Press 29, (1943): 119-20.

178 Eberle, op.cit., 55.

179 Ibid.

180 Antonio Buti, "The Removal of Aboriginal Children: Canada and Australia Compared," University of Western Sydney Law Review 6, (2002): 25.

${ }^{181}$ Ibid, 25, 29-30.

182 Ibid.

183 Ibid, 29-30.

184 Ibid 25, 29-30.

185 Ibid.

186 Ibid. Eberle, op.cit., 58. 
determine whether current solutions should be improved, or whether additional solutions are necessary. ${ }^{187}$

\subsubsection{Summary of Findings}

A comparative law perspective can be required in order to obtain an extensive understanding of ILIs in the Australian setting. ${ }^{188}$ This is because ILIs are embedded in a culturally unique context that is replete with concepts that are difficult to comprehend solely through an Australian legal perspective. 189 The 'law-in-context' method can be used to overcome this obstacle because it enables legal researchers to break through the cultural barriers that prevent ILIs from being adequately understood. ${ }^{190}$ And once such barriers are broken, comparative lawyers can convey specialist insights about ILIs using a range of methodology. ${ }^{191}$

\section{Conclusion}

ACL is not yet recognised to an adequate extent under Commonwealth law. Recognition of ACL to the fullest extent that is possible, where it does not conflict with Australian law and human rights, has the potential to deliver numerous positive outcomes. For example, the reinvigoration of oppressed Indigenous legal systems would help to fill a void in the lives of Indigenous people, and intercultural relations would improve exponentially.

The over-representation of Indigenous people in the criminal justice system stems at least in part from two issues: the personal 'cost' of committing a crime is lessened where a person feels unvalued; and the personal 'cost' of committing a crime is lessened where a person is unable to live out their life purposes.192 Australian law does not adequately express the value of Indigenous people. And the injustices of the past and present remind Indigenous people of this hurtful reality. Furthermore, poor social conditions are preventing many Indigenous people from fulfilling their life purposes. ${ }^{193}$ When the true issues giving rise to over-representation are addressed and resolved, contact with the criminal justice system will inevitably reduce. This is because solving these problems will in turn increase the personal 'cost' of committing a crime.

\footnotetext{
187 Buti, op.cit., 30-7.

188 Hoecke, op.cit., 16. Eberle, op.cit., 52.

189 Sackville, loc. cit.

190 Ibid. Hoecke, loc.cit. Eberle, loc.cit.

191 Hoecke op.cit., 8.

192 Gambetta, loc.cit.

193 Productivity Commission for the Steering Committee for the Review of Government Service Provision, op.cit., Chapter 4, 3.
} 
Indigenous property rights are not yet developed to the fullest extent possible. The concept of 'tradition' under the Native Title Act 1993 (Cth) is rigid and unfairly precludes legitimate claims. ${ }^{194}$ Furthermore, traditional Indigenous landowners of government-granted lands cannot economically progress due to the absence of private land ownership rights. ${ }^{195}$ Lastly, comparative lawyers are able to convey specialist insights about Indigenous legal issues that are surrounded by conceptual cultural barriers. ${ }^{196}$ For this reason, a comparative law perspective can be of value when attempting to understand Indigenous legal issues.

\section{BIBLIOGRAPHY}

\section{Books}

McRae, Heather, et al. Indigenous Legal Issues: Commentary and Materials. Sydney: Thomson Rueters, 2009.

Gambetta, Diego. Codes of the Underworld: How Criminals Communicate. New Jersey: Princeton University Press, 2009.

\section{Journal Articles}

Buti, Antonio. "The Removal of Aboriginal Children: Canada and Australia Compared." University of Western Sydney Law Review 6 (2002): 25-37.

Cohen, Marshall. "Law, Morality and Purpose." Villanova Law Review 10, no. 4 (1965): 640-654.

Eberle, Edward J. "The Methodology of Comparative Law." Roger Williams University School of Law 16, no. 1 (2011): 51-72.

Elliot, E Donald. "The Evolutionary Tradition in Jurisprudence," Columbia Law Review 85, no. 38 (1985): 38-94. https://doi.org/10.2307/1122404

Gaymarani, George Pascoe. "An Introduction to the Ngarra Law of Arnhem Land," NTLJ 1 (2011): 283-304.

Ginibi, Ruby Langford. "Aboriginal Traditional and Customary Laws" Law Text Culture 1 (1994): 8-12.

Gutteridge, H C. "Comparative Law and the Conflict of Laws," Transactions of the Grotius Society (Cambridge University Press 29. (1943): 119-141.

Hoecke, Mark Van. "Methodology of Comparative Legal Research," Law and Method, no. 12 (2015): 1-35.

Kelly, Danial. "Foundational Sources and Purposes of Authority in Madayin," Victoria University Law and Justice Journal 4, no. 1 (2014): 33-45. https://doi.org/10.15209/vulj.v4i1.40

Kelly, Danial. "Marriage Law in Madayin," Australian Law Journal 88, no. 8 (2014): 536-539.

194 Australian Law Reform Commission (ii), op.cit., 17-19.

195 Helen Hughes, Mark Hughes, and Hudson, loc.cit.

196 Hoecke op.cit., 16. Eberle, loc.cit. 
Kelly, Danial. "The Law of Sorcery in Madayin," $A L J$ 94, no. 1 (2020): 1-6 (forthcoming).

Morris, Jackie. "Sea Country - The Croker Island: Commonwealth of Australia v Yarmirr," Indigenous Law Bulletin 5, no. 14 (2002): 18-20.

Nettheim, Garth. "Developing Aboriginal Rights," Victoria University of Wellington Law Review 19, no. 4 (1989): 403-420.

Núñez, Rodrigo Míguez. "Indigenous Customary Law in a Civil Law Context: Latin America and the Chilean Case," Rechtsgeschichte - Legal History, no. 24 (2016): 302-313.

Sackville, Ronald. "Legal Protection of Indigenous Culture in Australia," Cardozo Journal of International and Comparative Law 11, no. 2 (2003): 711-745.

Schwartz, Melanie. "Redressing Indigenous Over-Representation in the Criminal Justice System with Justice Reinvestment," Precedent (Sydney, N.S.W.), no. 118 (2013): 38-41.

Simpson, Gerry. "Mabo, International Law, Terra Nullius, and the Stories of Settlement: An Unresolved Jurisprudence," Melbourne University Law Review 19, no. 1 (1993): 195-210.

Terrill, Leon. "The Days of the Failed Collective: Communal Ownership, Individual Ownership and Township Leasing in Aboriginal Communities in the Northern Territory," UNSW Law Journal 32, no. 3 (2009): 814-851.

Wallis, Rebecca and April Chrzanowski. "Addressing Indigenous OverRepresentation in the Australian Criminal Justice System: Some Thoughts about the Role of Legal Institutions as Stewards of a Complex System," Pandora's Box (2015): 37-47.

Whytock, Christopher A. "Legal Origins, Functionalism, and the Future of Comparative Law," Brigham Young University Law Review, no. 6 (2009): 1879-1905.

Wootten, Hal. "Occasional Address," UNSW Law Review 18, no. 2 (1995): 232236.

Yang, Kenny. "The Rise of Legal Positivism in Germany: A Prelude to Nazi Arbitrariness?" Western Australian Jurist 3, no. 9 (2012): 245-257.

\section{Theses or Dissertations}

Foley, Ashley M, "Terra Nullius: The Aborigines in Australia." Thesis., Salve Regina University, 2009

\section{Legal Documents}

Australia. Aboriginal and Torres Strait Islander Act 2005 (Cth).

Australia. Aboriginal and Torres Strait Islander Heritage Protection Act 1984 (Cth).

Australia. Aboriginal Land Grant (Jervis Bay Territory) Act 1986 (Cth).

Australia. Aboriginal Land (Lake Condah and Framlingham Forest) Act 1987 (Cth).

Australia. Aboriginal Land Rights (Northern Territory) Act 1976 (Cth). 
Australia. Crimes Act 1914 (Cth).

Australia. Criminal Code Act 1983 (NT).

Australia. Environment Protection and Biodiversity Conservation Act 1999 (Cth).

Australia. Environment Protection and Biodiversity Conservation Regulations 2000 (Cth).

Australia. Evidence Act 1995 (Cth).

Australia. Family Law Act 1975 (Cth).

Australia. Marriage Act 1961 (Cth).

Australia. Native Title Act 1993 (Cth).

Australia. Protection of Movable Cultural Heritage Act 1986 (Cth).

\section{Other Documents}

Aboriginal and Torres Strait Islander Social Justice Commissioner, "Native Title Report 2005 Report, 2005," https://www.humanrights.gov.au/sites/default/files/content/social_jus tice/nt_report/ntreport05/pdf/NativeTitleReport2005.pdf.

Australian Law Reform Commission, "Connection to Country: Review of the Native Title Act 1993 (Cth) Report No 126, April 2015," https: / / www.alrc.gov.au/wpcontent/uploads/2019/08/alrc_126_final_report.pdf.

Australian Law Reform Commission, "Recognition of Aboriginal Customary Laws Report No 31, June 1986," https://www.alrc.gov.au/wpcontent/uploads/2019/08/ALRC31.pdf.

Helen Hughes, Mark Hughes, and Sara Hudson, "Private Housing on Indigenous Lands Report, 2010," https://www.cis.org.au/app/uploads/2015/07/pm113.pdf.

Law Reform Commission of Western Australia (K Trees), "Contemporary Issues Facing Customary Law and the General Legal System: Roebourne - A Case Study (Background Paper No 6, 2004)," https://researchrepository.murdoch.edu.au/id/eprint/11948/1/contem porary_issues_facing....pdf.

Northern Territory Law Reform Committee, Parliament of the Northern Territory, "Committee of Inquiry: Aboriginal Customary Law (Report, 2003),"

https://justice.nt.gov.au/_data/assets/pdf_file/0011/238619/ntlrc_fin al_report.pdf.

Productivity Commission for the Steering Committee for the Review of Government Service Provision, "Overcoming Indigenous Disadvantage Report, 2016," https://www.pc.gov.au/research/ongoing/overcomingindigenous-disadvantage/2016/report-documents/oid-2016-overcomingindigenous-disadvantage-key-indicators-2016-report.pdf. 


\section{Case Law}

(Commonwealth of Australia v. Yarmirr), Judgment, 208 Commonwealth Law Reports 1, 2001.

(Love v. Commonwealth of Australia; Thoms v. Commonwealth of Australia), Judgment, Australian Law Journal Reports 198, 2020.

(Mabo v. Queensland (No 2)), Judgment, 175 Commonwealth Law Reports 1, 1992.

(Mehmet v. Carter), Judgment, NSWSC 413, 2020.

(Milirrpum v. Nabalco Pty Ltd), Judgment, 17 Federal Law Reports 141, 1971.

(Narrier v. State of Western Australia), Judgment, Federal Court of Australia 1519, 2016.

(The Queen v. Wunungmurra), Judgment, Northern Territory Supreme Court 24, 2009.

(Walker v. New South Wales), Judgment, 182 Commonwealth Law Reports 45, 1994.

(Western Australia v. Ward), Judgment, 213 Commonwealth Law Reports 1, 2002.

\section{Website Content}

Legal Monitor Worldwide, "I Want the True Law that Brings Peace and Harmony: Five Questions for Dianne Biritjalawuy Gondarra," https: / / cdu-edu-

primo.hosted.exlibrisgroup.com/permalink/f/7r169d/TN_gale_ofg38810 5271.

Macquarie Dictionary, "Definition of recognise,"

https: / /www.macquariedictionary.com.au/features/word/search/?searc h_word_type=Dictionary\&word=recognise.

Melinda Schroeder, "Northern Territory Law Handbook: Aboriginal Land, Native Title and Heritage," http:/ / ntlawhandbook.org/foswiki/NTLawHbk/AboriginalLandNativeTitl eAndHeritage. 